\title{
Central Asian Economies: Thirty Years After Dissolution of the Soviet Union
}

\author{
Richard Pomfret ${ }^{1,2}$
}

Accepted: 9 August 2021 / Published online: 30 August 2021

(c) Association for Comparative Economic Studies 2021

\begin{abstract}
In 2021, it is thirty years since the dissolution of the Soviet Union. This paper examines the evolution of Central Asia's five national economies since 1991 and their economic prospects. The 1990s were dominated by nation-building and the transition from central planning. By 2000, the transition from central planning was essentially complete and the varieties of market-based economies have changed little in the 21 st century. Political systems, established in the 1990s around a general pattern of strong presidencies, also changed little, apart from in Kyrgyzstan. Between 1999 and 2014, national economic fortunes were largely shaped by the resource boom. Since the end of the boom, to re-orient Central Asia from dependence on primary product exports and remittances to more diversified outward-oriented economies, domestic change will be necessary. This paper assesses the pressures for economic reform and the forces resistant to change. The economic context includes an improved infrastructure for overland trade across Eurasia as well as an uncertain global trading system and the consequences of the COVID-19 epidemic. The political context includes autocratic non-democracies with an elite that may be content with the unreformed economy, and generational change in leadership. Whereas the initial presidents had spent their entire lives in the planned economy, the current presidents have spent most of their adult lives in market-based economies, mirroring similar changes in the wider population, and may be less resistant to market-based reform and integration into the global economy.
\end{abstract}

\footnotetext{
ACES Presidential Address at the ASSA conference held online on 3-5 January 2021. I am grateful to conference participants who debated the address and to Joanna Lillis and Johannes Linn for helpful comments on an earlier draft. The paper draws on material in my keynote address at the Life in Kyrgyzstan conferences in Bishkek on 28-29 October 2020 and on comments from participants at the LiK conference. A less personal account of the period is in Pomfret (forthcoming) and on the twenty-first century in Pomfret (2020a).
}

Richard Pomfret

richard.pomfret@adelaide.edu.au

1 Professor of Economics Emeritus, University of Adelaide, Adelaide, Australia

2 SAIS Europe, Bologna, Italy 
Keywords Central Asia $\cdot$ Transition $\cdot$ Leaders

JEL Classification P30 $\cdot \mathrm{O} 53 \cdot \mathrm{P} 16$

\section{Introduction}

In 2021, it is thirty years since the dissolution of the Soviet Union. This paper examines the evolution of Central Asia's five national economies since 1991. The 1990s were dominated by nation-building and the transition from central planning. Despite initial similarities, the five countries created diverse market-based economies, ranging from possibly the most to the least radical reforms of all fifteen Soviet successor states. By 2000, the transition from central planning was essentially complete and the varieties of market-based economies have changed little in the 21st. century. Political systems, established in the 1990s around a general pattern of strong presidencies, also changed little, apart from in Kyrgyzstan.

Between 1999 and 2014, national economic fortunes were largely shaped by the resource boom. While the transitional recession of the 1990s had been more difficult than many expected, economic performance over the next fifteen years generally exceeded expectations. Since 2014, after the end of the boom, governments claim to recognize the need for economic diversification. To re-orient Central Asia from dependence on primary product exports and remittances to more diversified outward-oriented economies, domestic change will be necessary.

This paper assesses the pressures for economic reform and the forces resistant to change. The economic background is the types of market-based economies created in the 1990s ("Economic Background" section) and the related wealth structure ("Political Economy" section). The political context for reform in the 2020s includes autocratic non-democracies and generational change in leadership. Whereas the initial presidents had spent their entire lives in the planned economy, the presidents in 2021 have spent most of their adult lives in the post-independence market-based economies ("Pressures for Economic Reform and the Forces Resistant to Change" section). The economic context includes an improved infrastructure for overland trade across Eurasia ("A Window of Economic Opportunity?" section), as well as an uncertain global trading system and consequences of the COVID-19 epidemic.

Taking advantage of the Presidential Address format, in the first section I review the economic history of the Central Asian countries since independence through the lens of my own research and publications on the region. The most striking feature has been creation of sustainable national economies. The challenge of the 2020s will be to ensure that the economies have sufficient economic dynamism to provide for rising living standards and other goals. In the 2020s, there is a window of opportunity as previous challenges of landlockedness have been alleviated by improved transport infrastructure. Successful economies will improve their chances of taking advantage of the window of opportunity by reinvigorating economic reforms. A key question is whether generational shift in Central Asian leadership and in the population at large will create a fertile environment for political and economic reform, or 
whether established elites will maintain nondemocratic political systems and resist economic reform.

\section{Economic Background}

In July 1992, the new independent states of Central Asia joined the United Nations and had to select which of the UN's regional bodies they would participate in. The Central Asian countries and Azerbaijan joined the UN Economic and Social Commission for Asia and the Pacific (ESCAP). The ESCAP Secretariat had little idea of how to interact with formerly centrally planned economies and appointed me in December 1992 as Regional Advisor. The story that I was told was that because I had worked on Poland and China, I should be able to understand economies located somewhere in between.

In 1992, the Central Asian countries were unexpectedly in transition from central planning but had little conception of what they were transitioning to. Few if any economists in the new national governments had training in or experience of how market-based economies functioned. Governments received advice from international bodies, but ministers and officials had limited capacity to evaluate the economic advice. ${ }^{1}$

In the fifteen months that I worked with ESCAP, my role was often as an educator rather than as a policy adviser, and with more success when talking to younger policymakers than to ministers or deputy ministers. As an example, on the immediate question in 1992-1993 of whether to continue using the ruble, it was difficult to convince senior policymakers, who believed that hyperinflation was due to monopolies increasing prices, that monetary policy was the driver of hyperinflation. Either the ruble zone had to be reformed so that monetary policy could address the hyperinflation, or countries should issue national currencies and control their own monetary policy. Only Kyrgyzstan learned this lesson in the first half of 1993, while the other four Central Asian countries could not start to control inflation until after the collapse of the ruble zone in November $1993 .^{2}$

After returning to academia in 1994, I wrote The Economies of Central Asia (Pomfret 1995), which was quite successful in large part because it was the only book in English on the topic (monopoly has its benefits). The book introduced the Central Asian countries' economic background and described the initial construction of national economies after dissolution of the USSR. In 1992, the five economies

\footnotetext{
1 Although institutions such as the International Monetary Fund and the World Bank quickly became involved, the major economic powers paid little attention to Central Asia in the 1990s as Russia was distracted by transition and Chechnya, confidence-building with China proceeded slowly, the European Union was completing the Single Market and contemplating a doubling of membership, and the USA, like the EU, was more concerned about Russia and Ukraine than Central Asia.

${ }^{2}$ It was of course easier to blame monopolies and monetize budget deficits than to cut public spending or increase taxes. Confusion was also caused by the World Bank and IMF initially advocating retention of the ruble zone, based on optimum currency area theory (Odling-Smee and Pastor 2002; Pomfret 2002, 2016).
} 
could be treated as components of a common economic space with minor variations, although already in 1993-1994, economic differences were strengthening. By 2021, national differences are much stronger, although shared geography, history, and culture continue to provide a common background.

The big economic issue in the 1990s was the choice of transition strategy: shock therapy or gradualism, sequencing of reforms, and so forth. Among the thirty or so economies in transition, from central planning to market-based economies, the Central Asian countries were sometimes seen as a natural experiment with five countries starting from similar initial conditions and adopting very different transition strategies. An important lesson from the 1990s was that successful transition was not simply about allowing market-based prices to guide resource allocation, privatizing and restructuring state enterprises, implementing good trade and macroeconomic policies, and so on-all from a common starting point of discredited central planning. Successful transition also depended on institutional features, broadly defined. Uzbekistan benefited from Tashkent's history as administrative center of Tsarist and Soviet Central Asia. ${ }^{3}$ Kyrgyzstan introduced good reforms but suffered from lack of institutions needed for markets to flourish (e.g., property rights and rule of law, and trust of third parties) as well as a paucity of experienced administrators.

Advisers also underestimated the severity of the transitional recession in Central Asia, which was deeper and longer than in Eastern Europe. The economic shock of transition from central planning was exacerbated by the dissolution of the Soviet Union, resulting in breakdown of what became international supply chains, and by hyperinflation and collapse of the common currency area. As the region emerged from the 1996-1997 trough, it was hit by the further negative shock of the 1998 Russian crisis and debt default. Compounded by the psychological shock of the shift from being part of superpower to widespread poverty, the trauma of the 1990s would nourish a negative view of capitalism and of democracy, especially among older people whose employment prospects in the new economy were poor.

Influenced by the experience of East Germany and Central Europe where the economic significance of privatization had been moderated by the lack of valuable state assets and fairly rapid emergence of new enterprises, privatization in Central Asia was subject to limited oversight. Small-scale privatization was quick and simple as retail outlets and other small businesses were largely transferred to employees but restructuring and privatization of large enterprises were more complex, because some resource-based enterprises were valuable. In Kazakhstan, where citizens received vouchers with which to bid in auctions of state property, the transfer to private ownership was often non-transparent; outcomes were not necessarily inefficient, but they created gross income inequalities (see next section). In Tajikistan, the only large enterprise, the aluminum complex, was a major prize in the civil war, and after the war, struggle for control over cotton gins was often violent.

The "natural experiment" was never concluded. Coinciding with the completion of basic transition ("first-generation" market-enabling reforms in the taxonomy of

\footnotetext{
3 For example, the irrigation system was better maintained by Uzbekistan's government than in the other major cotton-producing republics, Turkmenistan and Tajikistan.
} 
Georgiev et al. 2017) in 1999 and before long-term consequences of transition strategies could be observed, the resource boom began. ${ }^{4}$ Kazakhstan's economy pulled away from the others and the countries that were poor in oil and gas, Kyrgyzstan and Tajikistan, fell behind; relative incomes in the twenty-first century bore little relationship to transition strategy. My book on The Central Asian Economies since Independence (Pomfret 2006) took the story up to the early 2000s.

The second decade after independence was dominated by the resource boom which powered rising incomes in Central Asia. The boom reduced the need for economic reform, either because increased oil and gas revenues removed pressure on public spending or because emigration and remittances provided a safety valve. Only after world energy prices fell definitively in 2014 (Fig. 1), followed by uncoordinated exchange rate volatility, did governments begin to acknowledge the need to diversify the national economies and that this would require renewed economic reforms. ${ }^{5}$

The third decade is the hardest to summarize as national experiences diverged. Output per head increased in all five countries during the boom years of 2000-2014 (Table 1). Living standards in Kazakhstan moved far ahead of the other countries but measured in any foreign currency units GDP was extremely volatile between 2014 and 2019 due to fluctuations in oil prices and exchange rates. Turkmenistan also enjoyed rapid economic growth, especially between 2006 and 2014 when payment for gas exports tracked world energy prices, but data remain opaque and income distribution very unequal. The Kyrgyz Republic and Tajikistan benefited from the boom mainly through remittances from migrant workers in Russia, which meant that they gained less than the energy exporters during the boom, but the drop in oil prices in 2014 had a less extreme impact. Uzbekistan, which became roughly self-sufficient in energy products and benefited from mineral exports and remittances during the resource boom lies in between the two country pairs.

A general observation is that governments have become less trepidatious about the world economy. After independence, regional leaders were suspicious of

\footnotetext{
${ }^{4}$ Georgiev et al. (2017) distinguish between "first-generation" (market-enabling) reforms-small-scale privatisation and liberalization of prices, interest rates and international trade; "second generation" (market-deepening) reforms - large-scale privatisation and establishing the main underpinnings of a commercial banking sector and capital markets; and "third generation" (market-sustaining) reforms-creation of economic institutions underpinning corporate governance and enterprise restructuring, competition policy, property rights and contract enforcement as well as framework for regulated sectors and public-private partnerships in infrastructure - that in many countries, including a number of advanced economies, remain largely incomplete. In Central Asia, reforms petered out around the time of the 1998 Russian crisis and at a lower level of completed transformation than in most other transition economies. The pattern was reflected in the EBRD transition indicators for Central Asian countries; virtually all improvements occurred before 1999 and the indicators changed little in the following decade.

5 Interpretation matters. Many accounts focus on financial crises and the shock to world trade in 20082009. For Central Asia, and for major trading partners Russia and China, the shock was brief and recovery rapid, implying that the national economies were resilient and reform unnecessary. Emphasis on the resource boom implies that global financial markets and aggregate world trade were less important for Central Asia than world prices of oil, gas, and some minerals; when the unsustainably high world prices fell, the Central Asian economies' resilience would be challenged, and the need for reform would become apparent.
} 
international trade and of global markets, apart from as outlets for their cotton, oil and gas, or minerals. Only Kyrgyzstan joined the World Trade Organization (WTO) during the 1990s; no other Central Asian country joined until 2012. The skepticism was clearest in Uzbekistan which is geographically the center of Central Asia but until 2016 imposed substantial costs on transit and discouraged international trade. My 2019 book The Central Asian Economies in the Twenty-first Century is sub-titled Paving a New Silk Road, reflecting the growing importance of international trade as the way forward for Central Asia. The new openness is reflected in the WTO accession of Tajikistan in 2012 and of Kazakhstan in 2015, revival of Uzbekistan's accession negotiations with expectations of early conclusion (Pomfret 2020b), and initiation in 2020 of Turkmenistan's WTO engagement.

In recent years, my research has focused on overland connections across Eurasia. Rail freight between China and Europe has grown from virtually zero before 2011 to over 300,000 containers per year in 2019 , and to over 550,000 in 2020 despite the COVID epidemic (see Table 4 below). These rail services currently transit Central Asia without carrying freight to or from the region. However, improved hard and soft infrastructure could provide a window of opportunity for Central Asian countries seeking to diversify their economies by broadening their export bundles. ${ }^{6}$ Which countries take advantage of the window will depend on their success in implementing economic reforms to reduce the costs of international trade, and of doing business in general.

\section{Political Economy}

A common (mis)perception outside the region in 1989-1991 was that all the formerly centrally planned economies would be in transition to market economies and democracy. In contrast to the situation in eastern Europe and the Baltics, the transition in Central Asia was not triggered by a popular revolt. Initial conditions such as low incomes and the absence of a large middle class were unfavorable for establishment of democracy (Acemoglu and Robinson 2006). Apart from in Tajikistan, the incumbent First Secretary retained power as national president. Although elections took place, these were mostly neither free nor fair and new constitutions explicitly concentrated power in the president's hands.

Privatization of state assets and state capture by an elite in the 1990s reinforced resistance to democracy. Specifics varied, but wealth accumulation was most associated with privatization of valuable state assets and with control over natural resource rents, banking and media, and telecomm licenses. ${ }^{7}$ In Kazakhstan, the beneficiaries

\footnotetext{
${ }^{6}$ Central Asia's comparative advantage in the traditional resource exports was sufficiently great that transport costs did not critically limit export earnings after independence, and especially after prices of oil, gas, gold, and other minerals soared in the early 2000 s.

7 Alexander and Heathershaw (2017) emphasize the significance of corruption and offshore financial links. See also the 2015 special issue of Central Asian Survey 34(1) on "Offshore Central Asia" edited by Alexander and Heathershaw.
} 


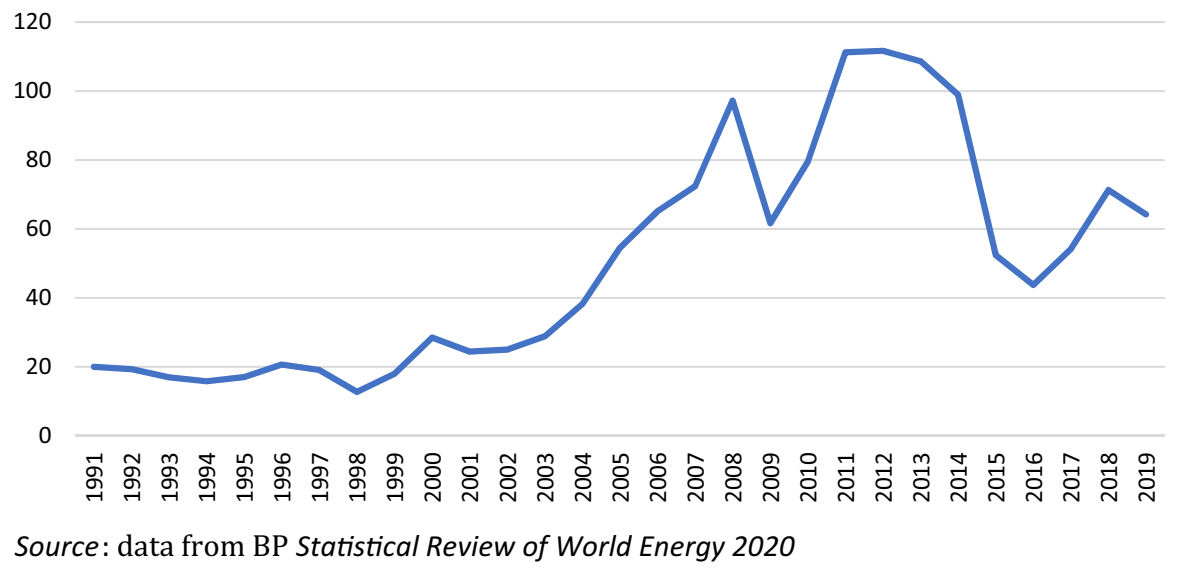

Fig. 1 Oil prices; Brent dated prices in USD per barrel, 1991-2019. Source: Data from BP Statistical Review of World Energy 2020, p. 26.

Table 1 GDP per capita, 2000-2019, current US dollars. Source: World Bank World Development Indicators at https://databank.worldbank.org/ source/world-development-indic ators. Accessed 20 July 2021

\begin{tabular}{lrrrrl}
\hline & 2000 & \multicolumn{1}{c}{2014} & 2016 & 2019 & 2020 \\
\hline Kazakhstan & 1229 & 12,807 & 7715 & 9813 & 9056 \\
Kyrgyz Republic & 280 & 1280 & 1121 & 1374 & 1174 \\
Tajikistan & 138 & 1104 & 807 & 891 & 859 \\
Turkmenistan & 643 & 7962 & 6398 & 7612 & n.a. \\
Uzbekistan & 558 & 2492 & 2568 & 1714 & 1686 \\
\hline
\end{tabular}

from privatization of mineral-related assets became very rich. ${ }^{8}$ In Tajikistan, a major economic prize in the civil war was the South Tajikistan complex of aluminum smelter and hydroelectricity generation. In all the countries, control over licenses for banks and mobile phone spectra yielded high rents. A common feature has been the concentration of wealth in presidential families; in Turkmenistan, the president became synonymous with the state (Mayne 2021), while in Uzbekistan, the president's elder daughter became especially hated and in the Kyrgyz Republic from the early 2000s until 2010 control over fuel supply to the US transit center at Manas airport was a source of large rents for the sons of presidents. Details of how wealth was acquired and used leaked out from court cases in Belgium, the Netherlands, Sweden, Switzerland, the UK and USA, although few cases ended with serious punishment.

\footnotetext{
${ }^{8}$ Kalyuzhnova (1998), Olcott (2002) and Pomfret (2005) described and tried to track the convoluted and non-transparent process. Some of the most contested resources, primarily involving control of minerals, were the subject of intra-elite battles for control. Burgis (2020) documents how the battles were won by friends of the president and that enemies of the president were relentlessly pursued to gain control of their assets.
} 
In Kazakhstan, a few people benefited especially from the privatization of mining companies. Vladimir Ni, who shared offices with Nursultan Nazarbayev in the Soviet era, was the original beneficiary of privatization of the copper mining conglomerate Kazakhmys; his protégé, Vladimir Kim, became Chairman of Kazakhmys (Global Witness 2010) and heads the Forbes rich list for Kazakhstan (Table 2). ${ }^{9}$ The "Trio"-Alijan Ibragimov, Patokh Chodiev and Alexander Mashkevich-benefited from privatization of chromium, alumina and gas. Bulat Utemuratov's company, Verny Capital, acquired the Vasilkovskoye gold mine in the 1990s and, after he sold the mine to Glencore International, Utemuratov retained a close relationship with the Swiss-based mining and commodities company, including participation in several very large transactions.

The other source of huge wealth in the 1990s was oil and gas contracts. Kazakhstan inherited the Soviet Union's largest foreign direct investment project, the agreement with Chevron to develop the Tengiz oilfield. ${ }^{10}$ The contract was revised several times during the 1990s, mostly with the assistance of a US lawyer, James Giffen; large unofficial payments accompanied each Tengiz revision and each new oil or gas agreement. The most high-profile legal case went to trial in the USA in the 2000s, inevitably earning the epithet Kazakhgate. ${ }^{11}$

Whereas the big money in the 1990s had come from privatization of state assets and oil and gas deals, in the 2000s, it came from obtaining licenses to operate newly booming activities such as TV and other media, mobile phone companies and the financial sector, and from receiving exemption from regulations or benefiting from other public policies. The presidential office controlled these access or regulatory paths to wealth. The main beneficiaries were the President's relatives and close associates such as Bulat Utemuratov. $^{12}$

\footnotetext{
${ }^{9} \mathrm{Ni}$ died in September 2010. Kim keeps a low profile and is reported living in Almaty and London, where he owns an apartment in One Hyde Park, "which its developers insist is the world's most exclusive address and the most expensive residential development ever built anywhere on earth" (Shaxson 2013).

${ }^{10}$ In the 1990s and early 2000s, foreign partners appear to have been necessary in oil and gas projects for their exploration, exploitation and exporting expertise, but not for the copper, chromium, iron ore and other minerals that underpinned the fortunes of Kazakhnmys and the Trio. In Table 2, "sources of wealth" and nationality are as cited by Forbes. Alexander Mashkevich, born in the Kyrgyz republic and now with dual Kazakh and Israeli citizenship, ranked 962nd and Patokh Chodiev, born in Uzbekistan and now a Belgian citizen ranked 1116th. The ethnicity of Kim and the Trio (Ibragimov is a Uighur born in Uzbekistan) ensured that they would not constitute a political challenge to Nazarbayev. Presidents are typically not included in the Forbes list, but Nazarbayev was often claimed to be among the world's richest.

${ }^{11}$ A Mobil vice-president was sentenced to 47 months in jail for failing to declare an unofficial payment for income tax. Two senior Kazakh officials $\mathrm{KO} 1$ and $\mathrm{KO} 2$ were included in the court documents but never indicted (LeVine 2007). Global Witness $(2010,15)$ claims that matching the US indictment to a related trial in Switzerland reveals the identities of KO1 as Oil Minister (and later Prime Minister) Nurlan Balgimbayev and KO2 as President Nazarbayev. Hersh (2001) reports extensive direct rent-seeking by President Nazarbayev as well as dealings through Giffen. In the US court case, Giffen pleaded guilty to a misdemeanor, receiving a small fine and no prison sentence; Horton (2010) ascribed the light sentence to pressure from US governments keen to preserve good relations with Nazarbayev.

${ }^{12}$ Utemuratov has been Secretary of the Security Council (2003-2006), head of the President's private office (2006-2008), and from 2008 to 2013 “adviser to the President". He sold ATF Bank to UniCredit of Italy for \$2.1 billion in 2007 and controls ForteBank. He owns two telecommunications operators, KarTel in Kazakhstan and SkyMobile in Kyrgyzstan, operating under the Beeline brand.
} 
Nazarbayev reacted forcefully to any opposition from within the elite. When in 2001, a group founded an opposition political movement, Democratic Choice of Kazakhstan (QDT), that called for the decentralization of political power, a strong legislature, and an independent judiciary to balance the power concentrated in the executive branch, the leaders were arrested and imprisoned. ${ }^{13}$ The most prominent target in 2001 was the president's son-in-law, Rakhat Aliyev, who was alleged to have been involved in kidnapping two senior managers in Nurbank; Aliyev was transferred to Kazakhstan's delegation to the OSCE in Vienna as a semi-exile. Later events reinforced the impression that any businessmen or officials appearing to challenge the president would be punished, e.g., the suspicious deaths of Zamanbek Nurkadilov in 2005 and of Altynbek Sarsenbayev in 2006. ${ }^{14}$ Corruption charges are selectively used and are sometimes seen as contrived. ${ }^{15}$

As oligarchs were put in their place outside politics and politicians' exposure was restricted, it became clearer that authority resided in the presidential office and that the central elite was the presidential family, who had become extremely wealthy, and trusted friends of the president. The wealth of President Nazarbayev and his eldest daughter, Dariga, remains a closely guarded secret, although proceedings in the UK in 2020 lifted the lid a little. In 2019, assets owned by Dariga Nazarbayeva and her son, Nurali Aliyev, including two mansions and a luxury apartment worth a total of $£ 80$ million ( $\$ 103$ million), were frozen under the Unexplained Wealth Act which allows the UK government to seize assets bought with proceedings from criminal acts; on 8 April 2020, the High Court in London ruled to lift the freeze after the assets' owners explained "how the sources of their wealth were legitimately acquired" (Leonard 2020). ${ }^{16}$ Second daughter Dinara Kulibayeva and her husband

\footnotetext{
13 Ibadildin and Pisareva (2020) provide a more detailed analysis of Nazarbayev's concentration of power in the presidency during the 1990s and his reaction to the 2001 "revolt of new Kazakhs". Burgis (2020) analyses the extraterritorial struggle over the assets and family of Mukhtar Ablayov, the most persistent opponent of the regime.

14 Rakhat Aliyev was later charged with ordering the murder of Sarsenbayev. In his book Godfather in Law, Aliyev claimed that the murder was ordered by Nazarbayev. The case is discussed but not resolved by Lillis (2019, 26-38), who also briefly discusses Nurkadilov's death (79-80). In 2007, Rakhat Aliyev was stripped of all official positions and divorced from Dariga Nazarbayeva. He was convicted in absentia in January 2008 of murdering two bankers and in February 2008 of treason. Living in Malta with his second wife (an Austrian citizen), Aliyev became an outspoken critic of the Kazakh regime. After Maltese authorities seized his assets in a European money-laundering case in May 2014, Aliyev turned himself in to Austrian authorities. In February 2015, he was found dead in jail as he awaited trial for money-laundering.

15 Satpayev (2014, p. 11) gives the following examples: Zhasylyk Doskaliev, former Minister of Health, sentenced to seven years in jail in 2011, Serik Burkitbaev, former Minister of Transportation and Communications, sentenced to six years' imprisonment in 2012, and Saiat Shaiakhmetov, Vice-Minister of Education and Science, convicted of embezzlement in 2013.

16 Dariga and Rakhat's elder son Nurali Aliyev assumed his father's wealth. In June 2018, the Panama Papers revealed that Nurali had two companies and a luxury yacht registered in the British Virgin Islands, which was not publicity the president liked to see. Dariga and Rakhat's younger son, Aysultan Nazarbayev, proved even more troublesome. After he accused close associates of the president (including Bulat Utemuratov) of corruption in 2017, his grandfather banned him from interfering in politics. In September 2019, Aysultan was arrested in London for burglary and assault on a police officer; he received a suspended sentence and was required to enter a rehab clinic. Aysultan died in August 2020.
} 
Table 2 Kazakhstani billionaires on Forbes rich list, 2019

\begin{tabular}{llll}
\hline World rank & Name & Net worth (USD) & Source of wealth \\
\hline 424 & Vladimir Kim & 4.6 billion & Mining \\
645 & Bulat Utemuratov & 3.5 billion & Mining, banking, hotels \\
715 & Timur Kulibayev & 3.2 billion & Banking \\
715 & Dinara Kulibayeva & 3.2 billion & Banking \\
1008 & Alijan Ibragimov & 2.3 billion & Mining, metals \\
\hline
\end{tabular}

Timur Kulibayev are extremely rich (Table 2). Dinara keeps out of the limelight, while Kulibayev is famous for associates in London who include Prince Andrew and Kazakh socialite Goga Ashkenazi, with whom he has two sons; the disrespect for Dinara earned President Nazarbayev's displeasure. The youngest daughter Aliya, like her nephews Nurali Aliyev and Aysultan Nazarbayev, has attracted the kind of publicity that the president himself shuns; her thirtieth birthday party in 2010 featured concerts costing \$2.4 million and gifts included a villa in Turkey and a yacht. ${ }^{17}$ Clearly the president's daughters are fabulously wealthy and are under their father's protection.

Nazarbyev was constrained in creating a hereditary succession, as in Azerbaijan and potentially in Tajikistan or Turkmenistan, because it is widely believed among the elite that Kazakhstan is not ready for a female president. His sons-in-law and grandsons have consistently failed to live up to the president's expectations of a potential successor, leaving Dariga as the only plausible successor from the family. When Nazarbayev chose to retire in March 2019, his selected successor was a loyal former minister.

Similar patterns of elite rule and snuffing out threats of revolt can be seen across Central Asia, although details are often opaque. Reports of plots foiled, e.g., in Uzbekistan in 1998 or Turkmenistan in 2002, are subject to conflicting interpretation. Spontaneous demonstrations in Andijon (Uzbekistan) in 2005 and in Zhanaozen (Kazakhstan) in 2011 were suppressed violently and quickly. Authoritarian regimes in Turkmenistan and in Tajikistan since 1997 tolerate little dissent. The only exception has been the Kyrgyz Republic, where street demonstrations led to the overthrow of presidents in 2005, 2010 and $2020 .^{18}$

A strong reason for continuing authoritarian rule in Central Asia, as elsewhere, is fear for the safety of the presidential family. While former presidents have protected their safety by going into exile in Russia or Belarus, their families are not immune

\footnotetext{
17 Aliya was married in 1998 to Aidar Akayev, son of President Akayev of the Kyrgyz Republic but the couple soon divorced. Aliya's second marriage in 2002 was to Dimash Dosanov, the General Director of KazTransOil.

${ }^{18}$ Kyrgyz President Akayev was the most liberal leader in Central Asia during the 1990s, although by the turn of the century he had lost personal popularity and was ruling by decree. Opposition was fueled by the corruption of his relatives; election of two of the president's children to parliament was a trigger for the street protests in 2005 that led to the abdication of Akayev, in part because he was unwilling to shed blood as Karimov did in Andijon in the same year.
} 
from acts that threaten their liberty or wealth. After his overthrow in 2010, Kyrgyz ex-president Bakiyev was sentenced to 24 years in jail for the murder of a senior official in 2009 and was also accused of mass murder over the shooting of dozens of people by police during the revolt that toppled him; his elder son Maxim was sentenced to twenty-five years in jail for corruption and his brother, Zhanysh, has been given a life sentence for murder. After the death of Uzbekistan President Islam Karimov in September 2016, his successor Shavqat Mirziyoyev, who had been Karimov's Prime Minister since 2003, showed little mercy toward Karimov's relatives. One daughter, Gulnara, is in jail and the other, Lola, is in exile; their children are in London. Lola's husband's extensive businesses in Uzbekistan have been seized. Relatives of Karimov's widow, Tatyana Karimova, who controlled many businesses in the Ferghana Valley also lost much of their wealth (Eckel 2018). In Kazakhstan, Nazarbayev is surely concerned about the security of his children and grandchildren and of their wealth if his family loses political control.

\section{Pressures for Economic Reform and the Forces Resistant to Change}

What are the prospects for economic reform in Central Asia? After the initial transition from central planning to market-based economies during the 1990s, the pace of reform slowed considerably. The resource boom reduced the pressure for reform as the hard times of the 1990s were followed by generally more congenial economic conditions between 2000 and 2014. Even after the economic warning signs appeared (falling export revenues or remittances), there was reluctance to make dramatic policy changes. The pattern is consistent with the argument of Hellman (1998) that the incumbent elite in post-Soviet states did not resist reform but sought a front-row seat in the resulting system. Members of the elite were happy with partial reform from which they could reap substantial rents but suspicious of radical reform that would destabilize and bring in new competitors both from domestic society and foreign investors. The reform process stalled in the 2000 s and was difficult to restart after 2014 because economic reforms always involve winners and losers, and the presidential families were themselves among the likely losers. A potentially favorable condition for reform has been presidential change in the two largest Central Asian countries, Uzbekistan in 2016 and Kazakhstan in 2019, in circumstances where there was no presidential son to maintain family control after Karimov died and Nazarbayev resigned.

Within Central Asia, there have been arguments about the extent to which the first presidents-exogenously determined by the Soviet Communist Party leadership-were important factors in explaining the type of market-based economy that was created and the economic growth record. ${ }^{19}$ There surely was some link, with

\footnotetext{
19 There is a lengthy international debate about the extent to which individual leaders have been good or bad for economic growth. Jones and Olken (2005), using death in office as an exogenous cause of leader change, found that the head of government matters for economic growth. In contrast, after disentangling country, year and other exogenous effects on the correlation between a leader's tenure and economic growth, Easterly and Pennings found that, of the 650 leaders in power between 1951 and 2014 for at least three years in countries with at least thirty years of continuous economic growth data (thus excluding former Soviet republics), only 26 had a statistically significant positive impact on their coun-
} 
Kyrgyzstan relatively fortunate and Turkmenistan unfortunate in the leader lottery. ${ }^{20}$ However, resource base and historical background have also been key determinants of national economic outcomes, and changes in leadership have not yet been associated with major policy change. Succession in Turkmenistan in 2006, Uzbekistan in 2016 and Kazakhstan in 2019 has been carefully orchestrated within the elite.

In 2021, does the personal background of individual leaders matter? Neither Rahmon's long tenure, construction of a family-based government and apparent grooming of his son as successor nor Berdimuhamedov smooth succession after Niyazov's death in 2006 provide optimism about future reforms, but pessimism can also be explained by the simple economic structure and opportunities for rent capture in Tajikistan and Turkmenistan; even in those two countries, there are signs of accommodation to the post-boom world, e.g., in their evolving position on the WTO. In the Kyrgyz Republic, despite a constitution giving more power to parliament since 2011 and peaceful changeover of elected presidents, the changes in president during the 2010s resembled power struggles among a poorly organized elite. These negative judgments are consistent with findings of Peveri (2021), who found that leaders with military or lower-level political backgrounds tend to perform poorest. ${ }^{21}$ In Peveri's study, leaders who had been high-level politicians (party leader or prime minister) do best as head of government. In the most diversified economies, the succession to Presidents Karimov and Nazarbayev was determined within the elite; both new rulers were former prime ministers. Mirziyoyev in Uzbekistan may have more freedom of action following a dead predecessor than Tokayev has in Kazakhstan with his predecessor in the wings.

More optimistically, the political context includes generational change in leadership. Whereas in 1991, the initial presidents had spent their entire lives in the planned economy, and the presidents in 2021 have spent most of their adult lives in their countries' post-independence market-based economies (Table 3). This mirrors similar changes in the wider population and in human capital. In sum, current leadership is more comfortable with market-based domestic economies and participation

\footnotetext{
Footnote 19 (continued)

try's economic growth and 18 had a negative impact. They find larger variance in the contribution to economic growth among leaders in non-democratic countries, but such leaders are no more likely to have a significant positive impact than democratic leaders. Easterly and Pennings (2020, p. 30) conclude that "it is very difficult to rigorously identify leaders who are good or bad for growth, and most leader estimates have wide standard errors". Based on analysis of the hereditary monarchs of major European states between the 10th and 18th centuries, Ottinger and Voigtländer (2020) find that the quality of the ruler (measured by degree of inbreeding) had a significant impact, both positive and negative, on a country's performance that was only moderated when parliaments constrained the hereditary ruler's power.

20 Tajikistan suffered most because competition for power between different elites was resolved in a deadly civil war that lasted until 1997.

21 Based on a sample of about a thousand national leaders from 1932 to 2010, Peveri (2021) identified five types of national leader and found significant and robust relationships between economic performance and quality of governance (identified by a method similar to Easterly and Pennings 2020) and leaders' background. Leaders who had been high-level politicians (party leader or prime minister) do best as head of government, while leaders with a military background do worst. Rahmon, Berdimuhamedov and Japarov could be classified as from low-level political or, in Rahmon's case, military background, which are associated with negative or statistically insignificant leader performance.
} 
in the global economy than the first presidents, and their populations will be more comfortable with market-based reforms than in the past.

The impact of changing values across generational cohorts has been applied to the evolution of Russian attitudes toward economic reform and democracy. Aslund (2019) traces a path from the market economy created by Yeltsin in the 1990s through a transition to autocracy and more state intervention in the economy during Putin's second term (2004-2008) that later degenerated into crony capitalism with asset-stripping (2008-2012) and more aggressive domestic and foreign policies since 2012. Implicit support for such a shift reflected concerns among older generations that they had lost out during the transition of the 1990s. In Central Asia too, many older former Soviet citizens draw a negative contrast between the chaos and economic hardship that accompanied the shift to capitalism and the economic and political stability of the 1964-1982 Brezhnev era, pointing to Brezhnev's success in improving living standards and maintaining domestic and international peace. ${ }^{22}$ Alexeev (2021) finds evidence that in both Russia and Ukraine the generations born before 1965 tend to have more authoritarian and anti-market values, while younger generations are more comfortable with market forces and with democracy. ${ }^{23}$ By that metric, the current generation of Central Asian leaders is still on the authoritarian side of the spectrum, but the youthful populations can be expected to be more liberal. Over half of the Central Asian population was born after 1980 and the median age of the population varies from 25 in Tajikistan to 32 in Kazakhstan.

\section{A Window of Economic Opportunity?}

The Central Asian governments have reacted to the end of the resource boom by acknowledging the need for economic diversification. Improved infrastructure, including for overland trade across Eurasia, provides a window of opportunity to develop new export-oriented activities. For Central Asian countries seeking to take advantage of better connectivity to expand non-traditional exports, domestic reforms will be necessary in order to improve the ease of doing business and to facilitate trade across borders. The extent to which the response will include real economic reforms rather than cosmetic changes in the face of opposition from an entrenched elite will be shaped by attitudes of leaders and citizens less firmly rooted in the centrally planned past.

In 1991, all roads, railways, air routes and pipelines led north from Central Asia to Russia. The Central Asian countries' role in the Soviet division of labor was as

\footnotetext{
22 The reference point for this rosy view is typically the era before Brezhnev's 1975 heart attack. By contrast, Western observers tend to recall the post-1975 Brezhnev years of economic stagnation and failure in Afghanistan.

23 Alexeev reports other influences, e.g. the rich are more authoritarian and the better-educated are more liberal, ceteris paribus. Surzho-Hamed and Turkina (2017) also find generational effects for Russia, and Norris and Inglehart (2019) make similar arguments at the global level.
} 
suppliers of raw materials: cotton, natural gas, and minerals. ${ }^{24}$ After independence, exports could be sold on world markets but establishing such trade depended on the product. Cotton's high value/weight ratio made it feasible to airfreight if cheaper means were unavailable. Gold was similar. For oil and, especially, gas, the most economic mode of transport was pipelines, but construction of new pipelines would be minimal until after energy prices increased in the twenty-first century. Non-traditional exports have been rare. ${ }^{25}$

Connectivity has improved dramatically over three decades. Pipelines connected Kazakhstan's oil-producing regions to the Black Sea, the Mediterranean and China during the 2000s and the Turkmenistan-Uzbekistan-Kazakhstan-China gas pipeline opened in 2009. Roads and airports have been upgraded, although improvement in air services has been mixed; Air Astana is the sole international-standard Central Asian airline and Turkish Air is the only external airline with a serious Central Asian network.A first rail connection with Iran opened in 1997 and Central Asia's rail infrastructure has improved dramatically, especially in Kazakhstan but also in Uzbekistan and Turkmenistan.

A driver of improved rail infrastructure has been the Eurasian Landbridge established since 2011. Freight between East Asia and Europe has traveled overwhelmingly by sea since 1500 . In the 2000s, European car companies started experimenting with bespoke train services to send European components to their Chinese assembly plant and electronics producers in western China (HP, Acer, Apple products) looked for faster routes to Europe. Regular train services were established in 2011 and are now offered between many cities. Freight forwarders provide additional services (part-container loads, refrigerated containers, onward multi-modal travel, etc). Rail transport between China and Europe offers reliable delivery in 12-15 days rather than an uncertain 40-50 days by sea, at a price that is attractive to traders with time-sensitive high value-weight items.

Rail freight along the Landbridge increased from negligible amounts in 2010 to 46,000 TEUs in 2015 and 333,000 TEUs in 2019. As maritime and air transport were disrupted by COVID-19 in 2020, rail traffic approached 550,000 containers (Table 4). The Landbridge overlaps with the Belt portion of China's Belt and Road Initiative (BRI), although it was market-driven and already well established by the time that the BRI was launched in May 2017. The BRI reinforces the sustainability of the Landbridge by guaranteeing Chinese political support and offering infrastructure finance. China originally referred to "One Belt One Road", but it is seeking multiple routes-north, south and across the Caspian Sea-to serve different cities,

\footnotetext{
${ }^{24}$ In the 1980s, infrastructure between Uzbekistan and Afghanistan was built, developing Termez as the principal access point for the Soviet military, but it had little economic significance in the 1990s. A Kazakhstan-China line completed in 1990 was the first Central Asia rail link not to go to Russia.

25 In the 2000s, the Kyrgyz Republic successfully exported beans (Tilekeyev 2013) and garments (Birkman et al. 2012; Jenish 2014; Tilekeyev et al. 2020), as well as acting as an entrepôt for the region (Kaminski and Mitra 2012). Uzbekistan had intermittent success exporting cars, usually through special arrangements (Pomfret 2019, pp. 110-111).
} 
Table 3 Central Asian leaders by date of birth

\begin{tabular}{lllllll}
\hline & \multicolumn{2}{l}{ December 1991 } & & January 2021 & & $\begin{array}{l}\text { Median age of } \\
\text { population 2019 }\end{array}$ \\
Kame & Date of birth & & Name & Date of birth & \\
\hline Kyrgyzstan & Akayev & 1944 & & Japarov & 1953 & 32 \\
Tajikistan & Nabiyev & 1930 & & Rahmon & 1968 & 27 \\
Turkmenistan & Niyazov & 1940 & & Berdimuhamedov & 1957 & 25 \\
Uzbekistan & Karimov & 1938 & & Mirziyoyev & 1957 & 30 \\
\hline
\end{tabular}

and also to avoid hold-up by a transit country. ${ }^{26}$ Currently, the trains take sealed containers through the transit countries without stopping, but improvements in the hard and soft infrastructure of trans-Central-Asian railways will open up potential outlets for non-traditional Central Asian exports. ${ }^{27}$

How important is improved infrastructure for economic development? The two are correlated but causality is difficult to identify because the relationship is twoway. Major studies have evaluated cases of exogenously determined transport investment, e.g., the Indian railway system, the first TransCanada railway or the US interstate highway system, that were built for military or political rather than economic reasons. ${ }^{28}$ Initial analysis emphasized the market-widening impact of improved transport that reduced the costs of trade, allowing greater realization of the gains from trade. More recent studies have included geographical effects of infrastructure change, in particular agglomeration effects that yield economies of scale and benefit people who move to urban areas while leaving depressed areas that are passed by and may go into economic decline. ${ }^{29}$

These analytical approaches have been combined in studies of the impact of the BRI, stimulated by empirical work at the World Bank. The World Bank analysis at sub-national level of all projects identified as part of the BRI is relevant to Central Asia because many projects included in the dataset are in the region (De Soyres et al. 2019). A striking result is that the locations most consistently benefiting from BRI projects are in the Kyrgyz Republic (Osh, Naryn, Talas, Batken), which is due

\footnotetext{
${ }^{26}$ Hold-up is a variation of the tragedy of the anti-commons, which occurs when excessive rent-seeking along a route makes trade unprofitable (Buchanan and Yoon 2000). A Central Asian example was the destruction of Kyrgyz onion exports to Siberia in the 1990s due to excessive official and unofficial levies while transiting Kazakhstan. China is keen to develop southern alternatives to the current Landbridge routes via Russia, but prospects depend on ease of transit. After the lifting of UN sanctions on Iran in January 2016, Chinese trains to Tehran transited Kazakhstan before following the Caspian coast through Turkmenistan, bypassing Uzbekistan because of that country's more cumbersome transit regulations. Since 2017, trains transit Uzbekistan after President Mirziyoyev eased border-crossing restrictions.

${ }^{27}$ The complementarity of hard and soft infrastructure is highlighted in the trade costs literature (e.g. Portugal-Perez and Wilson 2012).

${ }^{28}$ The historical literature is reviewed in Donaldson and Hornbeck (2016), Donaldson (2018) and Trew (2020).

${ }^{29}$ Costas-Fernández et al. (2020) show that the railway revolution in nineteenth century England and Wales led to better labor market matching and greater social mobility.
} 
to inclusion of present and future BRI road and rail projects; the model does not consider the cost or likelihood of completion of BRI projects. ${ }^{30}$ One of the most controversial of these projects, the Kashgar-Osh-Andijan rail link which would complete a shorter China-Uzbekistan-Iran connection, illustrates the difficult choices that have to be made. The rail link's estimated cost is roughly equal to the Kyrgyz Republic's GDP and financing by even a soft loan from China could create potential debt dependence (Hurley et al. 2018) because the projected line runs through sparsely populated Kyrgyz regions and transit revenues are uncertain.

The high costs of doing business in Central Asia have been highlighted in the World Bank's annual Doing Business reports. In 2015, the four Central Asian countries ranked among the eight worst of the 189 countries in the report (Turkmenistan was not included) for ease of crossing borders. The rankings improved in 2016, largely due to changes in methodology, but other indicators substantiate the ongoing high trade costs in money, time, and uncertainty of crossing Central Asian borders. ${ }^{31}$ In the 1990s, the high costs were routinely ascribed to landlockedness, but since 2005, it has become accepted that high trade costs reflect customs delay and behindthe-border practices which can be reformed. If reforms are implemented, Central Asia could become land-linked to dynamic trading partners and able to diversify exports to include more agricultural and manufactured products. ${ }^{32}$

\section{Conclusions}

The Central Asian countries have survived for three decades since 1991 and face no pressing existential threats-in sharp contrast to the new independent countries of $1919 .{ }^{33}$ Central planning has been replaced by national economic systems that vary substantially in the degree of state-control over market forces; all are characterized by imperfect institutions, corruption, and inequality. The political systems have more similarities, with super-presidential regimes in all except the Kyrgyz Republic (and in 2021 that country is reversing the empowerment of

\footnotetext{
30 The results reported here are from Bird et al. (2020), who estimate effects on real income under various assumptions about production patterns and labor movement. Although the map of BRI projects in Bird et al. (2020, Fig. 1) has a single category of "rail improvements", projects starting from Kashgar, the most western point in China's rail network since 2000, involve construction of new lines rather than upgrading of existing track, and routes from Kashgar to Tashkent, to Dushanbe and to Pakistan cross some of the world's highest mountains. Assuming completion of all these projects, Kyrgyzstan will become "a central country in the BRI network" (Bird et al. 2020, 12).

31 The most detailed and reliable data are in the CAREC Corridor Performance Monitoring and Measuring reports administered by the Asian Development Bank. See also Sharafeyeva and Shepherd (2020).

32 The argument that Central Asia could benefit from being land-linked to dynamic neighbors has been developed by Johannes Linn in several presentations (e.g. Linn 2012, 98).

33 Following the break-up of the Austro-Hungarian and Ottoman Empires and loss of territory of the former German and Russian Empires, Poland, Austria, Czechoslovakia, Yugoslavia, Estonia, Latvia, Lithuania, Hungary and Finland became independent countries and Romania was much increased in area. By 1942, the first seven of these countries had disappeared, while Finland, Hungary and Romania were under German influence and would lose territory in the 1945-1947 peace treaties.
} 
Table 4 Volume of traffic on China-EU-China container trains, 2015-2020. Source: Eurasian Rail Alliance at www. utlc.com. Accessed 20 July 2021

\begin{tabular}{ll}
\hline Year & $\begin{array}{l}\text { Number of twenty-foot } \\
\text { equivalent containers } \\
\text { (TEUs) }\end{array}$ \\
\hline 2015 & 46,000 \\
2016 & 104,500 \\
2017 & 175,800 \\
2018 & 280,500 \\
2019 & 333,000 \\
2020 & 546,900 \\
\hline
\end{tabular}

The Eurasian Rail Alliance (UTLC) was founded by Belarus, Kazakhstan and Russia in 2014 to provide services for container trains running between China and Europe. The UTLC data cover the main Landbridge routes, but not all routes

parliament and other checks on presidential power). The economic and political systems are inter-connected insofar as the political elite around the president is also an economic elite that has benefited from the collapse of central planning and is happy with the partially reformed economies of the early twenty-first century.

Some economic changes would have happened absent dissolution of the USSR but independence surely accelerated and exacerbated change. In the market-based economies created in the 1990s, new goods and services became more quickly available and new opportunities opened up for many people. At the same time, the 1990s saw severe hardship for most of the population, and economic uncertainty and inequality increased. Positive economic outcomes since completion of the transition around the turn of the century were largely driven by the resource boom, i.e., high world prices for oil and gas, gold and other minerals until 2014, rather than by emergence of new activities. Since the end of the resource boom, the need for economic diversification if the national economies are to prosper is widely recognized.

What are the prospects for increased incomes in the 2020s? Improved infrastructure in the twenty-first century has allayed the costs of landlockedness for Central Asia. Whether a country takes advantage of the window of opportunity to promote export-oriented economic growth will depend upon national reform to make economies more efficient and responsive to market incentives and to reduce the costs of doing business and of international trade. The lack of deep reform in the 1990s and creation of autocratic regimes with a conspicuously wealthy elite are ongoing obstacles to creation of well-functioning market-based economies. The resource boom, despite the obvious benefits of increased incomes, may have made post-boom reform more difficult as entrenched elites are content with the status quo. On the other hand, a new generation of leaders and peoples familiar with market-based economies and the world beyond the formerly centrally planned economies may be more receptive to reform. Resolution of these dilemmas will be decisive. 


\section{References}

Acemoglu, Daron, and James Robinson. 2006. Economic Origins of Dictatorship and Democracy. New York: Cambridge University Press.

Alexander, Cooley, and John Heathershaw. 2017. Dictators Without Borders Power and Money in Central Asia. New Haven, CT: Yale University Press.

Alexeev, Michael. 2021. Review of Russia's Crony Capitalism: The Path from Market Economy to Kleptocracy by Anders Åslund. Journal of Economic Literature 59(1): 220-243.

Åslund, Anders. 2019. Russia's Crony Capitalism: The path from market economy to kleptocracy. New Haven, CT: Yale University Press.

Bird, Julia, Mathilde Lebrand and Anthony Venables 2020. The Belt and Road Initiative: Reshaping economic geography in Central Asia? Journal of Development Economics 144.

Birkman, Laura, Maria Kaloshnika, Maliha Khan, Umar Shavurov, and Sarah Smallhouse. 2012. Textile and Apparel Cluster in Kyrgyzstan. Cambridge, MA: Harvard University Kennedy School and Harvard Business School.

Buchanan, James, and Yong Yoon. 2000. Symmetric Tragedies: Commons and Anticommons. Journal of Law and Economics 43: 1-13.

Burgis, Tom. 2020. Kleptopia. London: William Collins.

Costas-Fernández, Julián, José-Albreto Guerra and Myra Mohnen. 2020. Train to Opportunity: The Effect of Infrastructure on Intergenerational Mobility. CEDE Working Paper No.48, Universidad de los Andes, Colombia. Available at https://repositorio.uniandes.edu.co/handle/1992/48003? show $=$ full.

Donaldson, Dave. 2018. Railroads of the Raj: Estimating the Impact of Transportation Infrastructure. American Economic Review 108(4-5): 899-934.

Donaldson, Dave, and Richard Hornbeck. 2016. Railroads and American Economic Growth: A "market access" approach. Quarterly Journal of Economics 131(2): 799-858.

Easterly, William, and Steven Pennings. 2020. Leader Value Added: Assessing the growth contribution of individual national leaders. NBER Working Paper 27,153, National Bureau for Economic Research, Cambridge MA.

Eckel, Mike. 2018. Under New Uzbek Leadership, Even Predecessor's Widow, Family are in the Crosshairs, Radio Free Europe/Radio Liberty, 8 October. https://www.rferl.org/a/brides-of-fergh ana-under-new-uzbek-leadership-even-predecessor-s-widow-family-are-in-the-crosshairs/29531 301.html.

Georgiev, Yordan, Piroska Nagy-Mohacsi and Alexander Plekhanov. 2017. Structural reform and productivity growth in Emerging Europe and Central Asia, LSE Institute of Global Affairs Research Paper Series 02/2017, London.

Hellman, Joel. 1998. Winner Takes All: The Politics of Partial Reform in Postcommunist Transitions. World Politics 50(2): 203-234.

Hersh, Seymour. 2001. The Price of Oil. New Yorker, 2 July. https://www.newyorker.com/magazine/ 2001/07/09/the-price-of-oil

Horton, Scott. 2010. Kazakhgate ends with a Whimper. Harper's Magazine, 9 August. https://harpers. org/2010/08/kazakhgate-ends-with-a-whimper/.

Hurley, John, Scott Morris, and Gailyn Portelance. 2018. Examining the Debt Implications of the Belt and Road Initiative from a Policy Perspective, CGD Policy Paper 121. Washington, DC: Center for Global Development.

Ibadildin Nygmet, and Dinara Pisareva. 2020. Central Asia in Transition: Social Contract Transformation in Nazarbayev and Post-Nazarbayev Kazakhstan. In Anja Mihr (ed.) Transformation and Development: Studies in the Organization for Security and Cooperation in Europe (OSCE) Member States (Springer: Cham, Switzerland).

Jenish, Nurbek. 2014. Export-driven SME Development in Kyrgyzstan: The Garment Manufacturing Sector. Institute of Public Policy and Administration Working Paper No.26, University of Central Asia, Bishkek.

Jones, Benjamin, and Benjamin Olken. 2005. Do Leaders Matter? National Leadership and Growth since World War II. The Quarterly Journal of Economics 120(3): 835-864.

Kalyuzhnova, Yelena. 1998. The Kazakhstani Economy: Independence and Transition. Basingstoke: Macmillan. 
Kaminski, Bartlomiej, and Saumya Mitra. 2012. Borderless Bazaars and Regional Integration in Central Asia: Emerging patterns of trade and cross-border cooperation. Washington, DC: World Bank.

Leonard, Peter. 2020. Kazakhstan: Nazarbayev wealth ruling dismays transparency campaigners. Eurasianet, posted on April 9. https://eurasianet.org/kazakhstan-nazarbayev-wealth-ruling-dismays-trans parency-campaigners.

LeVine, Steve. 2007. Oil and the Glory: The Pursuit of Empire and Fortune on the Caspian Sea. New York: Random House.

Lillis, Joanna. 2019. Dark Shadows: Inside the Secret World of Kazakhstan (I.B.Tauris \& Co: London).

Linn, Johannes. 2012. Central Asian Regional Integration and Cooperation: Reality or Mirage? In Eurasian Integration Yearbook 2012 (Eurasian Development Bank: Almaty), 96-117.

Mayne, Tom. 2021. Turkmenistan: A model kleptocracy (Crude Accountability). https://www.civicsolid arity.org/sites/default/files/web_turkmenistan_a_model_kleptocracy_report.pdf..

Norris, Pipe and Ronald Inglehart. 2019. Cultural Backlash: Trump, Brexit, and Authoritarian Populism (Cambridge University Press: Cambridge UK). 2021. Turkmenistan: A model kleptocracy (Crude Accountability). https://www.civicsolidarity.org/sites/default/files/web_turkmenistan_a_model_ kleptocracy_report.pdf.

Odling-Smee, John, and Gonzalo Pastor. 2002. The IMF and the Ruble Zone. Comparative Economic Studies 44(4): 3-29.

Olcott, Martha Brill. 2002. Kazakhstan: Unfulfilled Promise. Washington, DC: Carnegie Endowment for International Peace.

Ottinger, Sebastian, and Nico Voigtländer. 2020. History's Masters: The Effect of European Monarchs on State Performance. NBER Working Paper 28,297, National Bureau for Economic Research, Cambridge MA.

Peveri, Julieta. 2021. The Wise, the Politician and the Strongman: National leaders' type and quality of governance. AMSE Working Papers 2120, Aix-Marseille School of Economics, France.

Pomfret, Richard. 1995. The Economies of Central Asia. Princeton, NJ: Princeton University Press.

Pomfret, Richard. 2002. The IMF and the Ruble Zone. Comparative Economic Studies 44(4): 37-48.

Pomfret, Richard. 2005. Kazakhstan's Economy since Independence: Does the oil boom offer a second chance for sustainable development? Europe-Asia Studies 57(6): 859-876.

Pomfret, Richard. 2006. The Central Asian Economies since Independence. Princeton, NJ: Princeton University Press.

Pomfret, Richard. 2016. Currency Union and Disunion in Europe and the Former Soviet Union. Cesifo Forum 17(4): 43-47.

Pomfret, Richard. 2019. The Central Asian Economies in the Twenty-first Century. Princeton, NJ: Princeton University Press.

Pomfret, Richard. 2020b. Uzbekistan and the World Trade Organization. Silk Road: A Journal of Eurasian Development 2(1): 54-61.

Pomfret, Richard. 2020a. The Central Asian Countries' Economies in the Twenty-First Century" in Alexandr Akimov and Gennadi Kazakevitch eds. 30 Years since the Fall of the Berlin Wall: Turns and Twists in Economies, Politics, and Societies in the Post-Communist Countries (Palgrave McMillan, 2020), 31-56.

Pomfret, Richard. Forthcoming. Economic Reform and Development in Central Asia. In Rico Isaacs and Erica Marat eds. The Handbook on Contemporary Central Asia (Routledge; London).

Portugal-Perez, Alberto, and John Wilson. 2012. Export Performance and Trade Facilitation Reform: Hard and soft infrastructure. World Development 40(7): 1295-1307.

Satpayev, Dossym. 2014. Corruption in Kazakhstan and the Quality of Governance. IDE Discussion Paper No.475, Institute of Developing Economies, Chiba, Japan.

Sharafeyeva, Alfinura, and Ben Shepherd. 2020. What does "Doing Business" really measure? Evidence from trade times. Economics Letters 192 (issue C).

Shaxson, Nicholas. 2013. A Tale of Two Londons. Vanity Fair, April. https://www.vanityfair.com/style/ society/2013/04/mysterious-residents-one-hyde-park-london.

Soyres, De., Alen Mulabdic François, Siobhan Murray, Nadia Rocha, and Michele Ruta. 2019. How Much will the Belt and Road Initiative reduce Trade Costs? International Economics 159: 151-164.

Surzho-Hamed, Lena, and Ekaterina Turkina. 2017. Post-Soviet legacies and Conflicting Values in Europe: Generation Why (Rowman \& Littlefield, Lexington Books: Lanham MD).

Tilekeyev, Kanat. 2013. Productivity Implications of Participation in Export Activities: The case of farmers in Talas Oblast of Kyrgyzstan. Institute of Public Policy and Administration, Working Paper No.17, University of Central Asia, Bishkek. 
Tilekeyev, Kanat, Bakytbek Tokubek and Dilbara Kirbasheva. 2020. The Garment Sector and Youth Employment in Kyrgyzstan: A Value Chain Analysis. Institute of Public Policy and Administration Working Paper No.57, University of Central Asia, Bishkek.

Trew, Alex. 2020. Endogenous Infrastructure Development and Spatial Takeoff in the First Industrial Revolution. American Economic Journal: Macroeconomics 12(2): 44-93.

Witness, Global. 2010. Kazakhstan, Kazakhmys PLC and the London Stock Exchange, Risky Business. London: Global Witness.

Publisher's Note Springer Nature remains neutral with regard to jurisdictional claims in published maps and institutional affiliations. 